\title{
The Great Leap from Earth to Heaven: The Evolution of Ballet and Costume in England and France in the Eighteenth Century
}

\author{
By MARY COLLINS AND JOANNA JARVIS
}

The evolution of classical ballet from its accepted origins as one method of displaying status and aristocratic power in Renaissance Italy to its Romantic form, featuring professional ballerinas in white costumes dancing en pointe, took place largely during the long eighteenth century. This article discusses this transformation from the dual perspectives of choreography and costume by using the premise that these two vital elements in the presentation of ballet were co-dependent, each prompting the other to develop and evolve. Concentrating on Paris and London, it examines the relationship between court dress, fashion, and theatre costume, and how this affected both the choreography and the style of dance throughout the long eighteenth century

KEYWORDS: eighteenth century, ballet, costume, baroque, theatre, Louis XIV

INTRODUCTION

The eighteenth century saw the significant transformation of ballet from its early origins as a lavish aristocratic entertainment in Renaissance Italy to the form we now know as classical ballet, featuring professionally trained dancers dressed in white dancing on their toes en pointe - the Romantic image of ballet so familiar today. Most current definitions of ballet mention the formal gestures, steps and poses, and the costumes and scenic effects which ballet as an art form employs 'to convey a story, theme or atmosphere'. ${ }^{1}$ From the spectacles at the French court of King Louis XIV $(1638-1715)$ and the earliest appearances in the seventeenth century of professional dancers at the Paris Opéra, to the seminal ballets, Flore et Zephyr by Charles Didelot (1767-1837) in 1776 and La Fil Mal Gardée by Jean Dauberval 
(1742-1806) in 1789, the essential elements of costume, dance technique and style changed radically.

Taking a chronological approach, we begin in the 1660s, in the middle years of Louis XIV's reign, when the focus for dance moved gradually from the court to the theatre, and professional dancers began to appear. The article investigates the factors which reversed the early eighteenth-century theatre convention of representing ancient gods descending to earth, so that by 1800 man is himself depicted attempting to ascend to heaven. The first professional female dancers are recorded appearing as early as 1681 dancing at the Académie Royale de Musique (later to become the Paris Opéra). ${ }^{2}$

The Regency of Philippe d'Orléans (1674-1723) from 1715-1723 during the minority of King Louis XV (1710-1774), saw the consolidation of a professional regime at the Paris Opéra which regulated and codified both court and theatre dance, producing the first internationally renowned dancers, both male and female. Performances on the stage became ever more elaborate and in its role as the European leader of ballet as an art form, the Paris regime set the parameters for movement and costume, which became gradually more restrictive. However, the third quarter of the century reflected a desire to move away from the strictures of the Paris Opéra and to create a new form of dance that told stories entirely through mime. Focus shifted away from gods and goddesses, and concentrated more on human dilemmas and emotions. It was the era of ballet d'action. The final years from 1789 brought the upheaval of revolution in France. This revolt against constraint and control was mirrored at the Opéra which was ultimately forced to employ costumes that released the body to move more freely, and expressed the new fascination with classical lines.

BEFORE 1700: BALLET DE COUR 
Ballet at the court of Louis XIV was presented as part of a spectacle of music, dance and voice designed to dazzle and impress the courtiers, ambassadors and other visitors who formed the audience with the wealth, taste and magnificence of his court. In England the masque, another composite form of court spectacle, had performed a similar function earlier in the century.

Louis XIV was acknowledged to have been an accomplished dancer, 'Since his childhood, this prince, who had received from the hand of Nature a noble and majestic figure, had loved every sort of physical exercise and had added to his natural gifts every grace that could be acquired. ${ }^{3}$ He displayed his talents frequently in entertainments known as ballets de cour. Supporting roles were taken by aristocratic amateurs, those who had the social status to perform alongside him. The formal intricately patterned choreographic figures within these court ballets demanded only that those courtiers who danced should stand and move with strength and elegance in order to enact their roles. This dance noble style represented such courtly attributes as elegance, nobility, generosity and honour. ${ }^{4}$

Costumes for the dancers participating in these court entertainments were heavily embellished and decorated, not only to depict the character being represented but also to dazzle the spectator. The costume design for Louis XIV's appearance as Apollo in Le Ballet de la Nuit in 1653 clearly illustrates the male style (Figure 1). Louis is shown wearing a classical-style Roman breastplate, fitted to the form of his body and worn with tunic and heeled shoes. His helmet is surmounted by tall plumes in accordance with convention. Feathers had come to signify gods and heroic characters; the feathers added height and grandeur to these characters' presence, and allowed them to be easily distinguished, even at the back of a dimly-lit stage. The stiff ruff of the previous era which had restricted head movements has gone, and the padded sleeves, soon to disappear, are softer allowing for greater arm movements. The Italian designer Stefano della Bella (1610-1664) among others, 
was summoned to France to design for the court in 1645, bringing with him this Italian classical style for male costuming. ${ }^{5}$ In England the Italian style of design was imported much earlier by the architect and designer Inigo Jones (1573-1652), who had travelled across Italy between 1596 and 1604. He was responsible for settings and costumes for most of the masques produced at the Stuart court of King Charles I (1600-1649).

Women's costumes, essentially an embellished form of court dress, were more restrictive, as can be seen in a c.1700 engraving of Mademoiselle Marie-Therese de Subligny (1666-1735), one of the first female professional dancers at the Paris Opéra (Figure 2). ${ }^{6}$ The diminishing size of bulky sleeves in fashionable dress from the middle of the century meant that elegant arm gestures were now possible for women, but heavy skirts and long trains would have been inhibiting and hidden any footwork, thus making the women's movements generally more limited than men's. By the 1660s Henri Gissey (c.1621-1673), who is thought to have designed Louis's Apollo costume, had been appointed as costume designer at the French court. Gissey created many dramatic and fantastic costumes for ballets which required zephyrs, nymphs, and other mythical beings, alongside the usual gods and goddesses.

The Roman style of skirted tunic for men, later referred to as a tonnelet, allowed them to perform jumps, turns, complex footwork, both à terre (on the ground), and en l'aire (raised), in what was later known as a half-aerial position. ${ }^{7}$ The heeled shoes required dancers to use pliés (bending the knees outwards with a straight back), and demi-pointe (heels raised with the weight on the balls of the feet), in order to articulate phrasing when dancing. They also demanded a more exaggerated turning-out of the feet than is otherwise natural. The audience would have instantly recognised the classical iconography displayed on the costumes, the golden rays of the sun representing Apollo, or a lion skin and club denoting the character Hercules, for example. Rules for costuming were written down in 1681 by Le 
Père Ménestrier (1631-1705) in Des Ballets Anciens et Modernes. ${ }^{8}$ He tells us that the costume for the Sun should be 'cloth of gold with a gilt headdress'; with a silver version to denote the Moon. ${ }^{9}$ The goddess Diana, the huntress, would always appear carrying a bow, wearing an animal skin and a moon motif (usually as a headdress).

As he grew older, Louis retired from appearing in ballets de cour but remained a staunch supporter of the art of dancing. With the formation of the Académie Royale de Dance in 1661, and the Académie de l'Opéra in 1669 (later known as the Académie Royale de Musique), Louis sought to raise both the technical and artistic standards of dance and choreography in order that even more spectacular entertainments could be created, and so that professional dancers could be trained to appear in them.

One of the first of these professional dancers was Jean Balon (1676-1739), who joined the dance Académie in 1691 and became a popular virtuoso during the later years of the reign of Louis XIV. ${ }^{10}$ The first female professional to appear was a Mademoiselle Lafontaine (1665-1738), who was recorded as dancing in Jean-Baptiste Lully’s (1632-1687) Triomphe de l'Amour in 1681. ${ }^{11}$ (Figure 3) Another prominent principal dancer, Mademoiselle Subligny, succeeded her as France's 'Queen of Dance' in $1688 .{ }^{12}$ Referred to as danseurs seria these professional dancers generally took the roles of deities, heroes and monarchs. They undertook a seven year training programme which consisted of classes with a designated Master (Maître), followed by a gradual introduction into performances at court or at the Opéra, beginning in the chorus and coryphée ranks before moving up to leading roles as a principal dancer. ${ }^{13}$

Dancing institutions at this time used a written system of symbols to record choreographies; principally Feuillet notation (Figure 4) which is alleged to have been the invention of Louis XIV's dancing master, Pierre Beauchamp (1631-1705). These intricate 
diagrams, printed alongside the music, were developed to transmit the precepts, rules and steps of danse noble. ${ }^{14}$ Feuillet-Beauchamp notation and the accompanying treatises which began to be published from the start of the eighteenth century onwards, show that dancers moved mainly on three levels; in demi-plié with knees bent, the knees being directly over the line of the toes without lifting the heels from the floor, à terre with feet flat on the ground, or on demi-pointe standing on the balls of the feet, heels off the ground (en relevé in classical ballet). Footwork was rhythmically intricate, operating almost as another line of the music. Kellom Tomlinson (1688-1761) the celebrated English choreographer, dancing master and composer, remarked in his seminal work The Art of Dancing (1735), that:

'the Music seems to inspire the Dancing, and the latter the former: and the Concurrence of both so requisite to charm those who behold them, that each of them in some Measure suffers by a Separation. ${ }^{15}$

Intricate beats and virtuosic waving of the feet whilst turning or maintaining perfect balance were possible and were frequently employed by male dancers - rarely by female dancers. Springs or jetés were mainly employed by men and were generally near the ground.

For such accomplished danseurs seria in their noble and heroic roles, suitably spectacular costume design was essential. By c.1674 Jean Bérain (1637-1711) had succeeded Henri Gissey, designing costumes that demonstrated elegance, imagination and wit. ${ }^{16}$ Like Gissey's designs, Bérain's creations were closely connected with court dress in silhouette, but embellished with embroidery, spangles and motifs in order to catch the light and to give an indication of the role. The move to the long, narrow Baroque stage from the more intimate 'in the round' setting at court had implications for costume and its visibility. Because the audience now viewed the stage from one perspective and at a greater distance, the detail added to dress needed to be exaggerated in order for it to be 'read' by the audience. 
Stage costumes were made of heavier fabrics and were more layered than in court dress; headdresses were wider and higher while flounces on sleeves were fuller and longer, giving greater emphasis to every gesture.

1700 - 1725: BALLET IN THE THEATRE

The beginning of the eighteenth century was a period of enormous development for the ballet when the traditions of dance established by Louis XIV firmly transferred from the court to the theatre stage, as the elderly monarch withdrew from performing. France now dominated music and dance across the continent, as was made clear by the French dancing master Pierre Rameau (1674-1748), who in 1725 stated that 'there is hardly a court in Europe where the dancing master is not French'. ${ }^{17}$ Publications by leading international dancing masters, including John Weaver (1673-1760), and Kellom Tomlinson in England, bear this out. ${ }^{18}$ The Bolognese poet and librettist, Pier Jacopo Martello (1665-1727) tells us:

The Frenchman dances in a way that gives you the impression that he is swimming. His arms, always raised and supple [...] his waist [...] following the motion of a current with its gentle bendings. From time to time he skips, as a swimmer who lets the crest of a wave push him high in order to be carried forward [...] with such grace that one is enchanted [...]. This style of dancing greatly pleases the French, who are disposed towards amorous attitudes. $^{19}$

This is a perfect description of the contretemps step or its adaptation, the baloné, for which Jean Balon was famous.

The 1681 print of Triomphe de l'Amour in the Bibliothèque Nationale de France clearly shows the attitudes of which Martello speaks (Figure 3). It also depicts a new style of staging 
that had become necessary due to the introduction of the proscenium arch which separated the performing space from the audience, framed the action, and enabled a single perspective to lead the eye to the central triumphant god or hero. This use of perspective was also employed in conjunction with a clever mirroring of the central heroic figure on stage with the central position of the French king's throne in the audience. The king's power and status was therefore reinforced despite the fact that he was no longer dancing. On stage, impressive, tableaux could be created, as seen in the Triomphe de l'Amour print, simply by using pattern, gesture and costume to great effect.

The Italian designer Giacomo Torelli (1608-1678), who was brought to Paris to design the production La Finta Pazza in 1645, had equipped the Théâtre du Petit-Bourbon with the style of elaborate machinery which had been in use in Italy since the late fourteenth century, and which had already been employed by Inigo Jones in England earlier in the century. The Paradiso, a system of ropes and pulleys, enabled whole choruses of heavenly creatures to descend, while the revolving triangular columns known as periaktoi permitted rapid changes of scene. Torelli also introduced the proscenium arch as a frame for the action. ${ }^{20}$ These Italian machines allowed stage directors to create astounding special effects: deities could descend from the heavens to dance upon the earth, spreading their beneficence, whilst other gods watched and sang from above. The political message was that, if the king is represented as a god, however bad things may become he can 'descend' to dispense his wisdom and bounty, restoring order and harmony for the lesser mortals, his subjects.

Because such performances were sponsored by the king within the context of court life, designers such as Jean Bérain were employed to produce costumes which reflected the opulence and status of both the aristocratic performers and their monarch. Bérain's costumes for female performers, although following the silhouette of court dress, were more heavily embellished with decoration. Skirts were layered and included at least one over-skirt, shorter 
at the front and falling to a train at the back. His costumes for men followed the tradition of the style á la Romaine, with tight fitting body and skirted tunic. Bérain was also a designer of furniture, tapestries and other decorative arts, an aspect highlighted by the bands of decoration on the costumes that clearly echo patterns seen throughout all of his designs. $\mathrm{He}$ soon began to design the settings for the stage as well as the costumes. In contrast to the statuesque figures of the heroic characters his designs for the more fantastical characters, such as marine gods and goddesses with their scales and shell patterns, and winds with feathers and wings, display his inventiveness. The same could be said of the costume designs for symbolic figures such as music and architecture, which are heavily decorated with motifs that give a sculptural quality to the costume. Inhibiting movement they reflect the fact the choreography itself was statuesque and generally moved from one tableau to another. Bérain was succeeded by his son, also Jean Bérain (1678-1726), whose design style closely mirrored his father's.

By 1720 Claude Gillot (1673-1722), in whose studio Jean-Antoine Watteau (16841721) was an apprentice, had become chief designer to the court. Gillot is chiefly remembered for his designs for the ballet Les Éléments of 1721 which show a real departure from the previous style. ${ }^{21}$ His costumes were not covered in heavy embroidery as were Bérain's, but used lighter fabrics, responding to the dancers' physical requirements as more complex moves were now being employed in the choreography. ${ }^{22}$ In Gillot's designs, the silhouette is still based on court dress and shows the arrival of wider hoops for women, but with the lighter fabrics and softer colours they move dance costume further away from the stiff formality of court dress and bring an even greater element of fantasy to the characters being created. ${ }^{23}$ For example a design for Folly shows a dress covered in rows of flounces, and The Hours of the Night wears a dark dress covered in stars with the Roman numerals of a clock spread around the hem. The lighter style of these designs suggests a greater 
understanding of the dancer's needs; however, Gillot still tended to exaggerate the male tonnelet for noble characters, taking it almost to the dimensions of the female hoops. This mirrored the power to dominate physical space previously associated with exaggerated female styles, especially those with wide hoops. This curious, stylized silhouette can be seen across Europe during this period, even being worn by actors for leading tragic roles. The English actor James Quin (1693-1766), known for his work as a tragedian was depicted playing Coriolanus in 1749 wearing a strange extended skirt akin to a tonnelet.

In England in the early part of the century ballet was developing along different lines. Theatrical dancing was performed between the acts of plays to divert the audience during lengthy costume or scene changes. These dances were often entirely unrelated to the drama. John Weaver, ballet master and manager at Drury Lane theatre in London and writer on dance, spent his life trying to elevate the status of the art. His most famous production, The Loves of Mars and Venus (1717), combined mime and plot with dancing to tell a story and therefore conforms, for the first time, to the current definition of ballet. In his preface he wrote, 'I have endeavour'd to enter into the Characters, I represent and describe their Manners and Passions by proper Actions and Gesture suitable to the Fable. ${ }^{24}$ An engraving by Canaletto (1697-1768) of the 1758 production of Le Turc Genereux in Vienna gives a fair impression of Weaver's gestures in action (Figure 5), and shows how the style continued to influence choreographers such as the Austrian Franz Hilverding (1710-1768) and the Frenchman Jean-Georges Noverre (1727-1810) in successive decades. Gestures were still fairly stiff 'attitudes' with arms based upon French dance noble style. Weaver chose the accomplished and popular dancer Hester Santlow (c.1690-1773) to dance Venus, and the production was staged at Lincoln's Inn Fields by John Rich (1692-1761), a champion of such hybrid performances that alternated serious scenes with Harlequinades, grotesque episodes, dance, and song. ${ }^{25}$ 
Italian commedia dell'arte, with its mix of improvised comedy and slapstick, and played by such stock characters as Harlequin, Columbine, Scaramouche and Pantalone, had been a popular draw at the London fairs since the previous century. ${ }^{26}$ Popular characters like Harlequin began appearing on stage and remained in demand throughout the century; the manager of Lincoln's Inn Fields Theatre, John Rich (1692-1761), was himself a brilliant Harlequin, as was David Garrick (1717-1779). The dancer Hester Santlow was also associated with the role. Wife of the Drury Lane actor-manager Barton Booth and a celebrated dancer on the London stage, Hester Santlow can be seen in John Ely's portrait of c.1720 (figure 6) portrayed as the character she created, a female version of Harlequin complete with slapstick and hat. Harlequine was not a female partner for Harlequin but a solo character in her own right, and Santlow was constantly in demand for her interpretation of this role. ${ }^{27}$ John Essex wrote in the preface to his 1728 translation of Pierre Rameau's Le Maître à danser (1674-1748)' 'the Produce of the many different Characters she represents is the Wonder and Admiration of the present Age [...] Besides all this, the Harlequin is beyond Description. ${ }^{28}$ Her husband, Barton Booth, tells us: 'She whirls around! She Bounds! She springs! As if Jove's Messenger had lent her wings. ${ }^{29}$ Women's technique was at last catching-up with the men's. It is worth noting that two other important French dancer/choreographers, Marie Sallé (1707-1756) and Jean-Georges Noverre both made significant steps in the development of their art after visiting the vibrant dance scene in London.

An engraving of another French dancer who had performed in London, a Monsieur Dubreil (fl. 1711 -1733), depicts him dancing le Scaramouche (Figure 7) at the Paris Opéra in 1711. ${ }^{30}$ Dubreil's pose makes it evident that French principal dancers who could dance in the comic or grotesque style had already incorporated popular acrobatic techniques into their repertoire to produce a more aerial, elegant form of pantomime. Movements were more 
stretched and exaggerated, involving greater elevation of both arms and legs, particularly typical in the role of Scaramouche. He is shown wearing a long-sleeved fitted tunic with a soft ruff and knee-breeches without padding, a costume which would have allowed him a much wider range of movement.

French danse noble, however, was mainly à terre - Rameau claimed that, 'dancing is no more than knowing how to bend and straighten the knees at the proper time' ${ }^{31}$ He was obviously referring to social dancing here though he also mentioned steps used in theatrical dance which are a little more difficult. For example:

Battements are movements off the ground made by one foot while the body is supported on the other, and make dancing very brilliant [...] Jetés can $[\ldots]$ be done in another manner which requires more strength in the hop. This is done by rising much quicker, sharply extending the legs, beating one against the other, and falling on the demi-pointe contrary to that on which the bend was made. They then have a different name and are called demicabrioles. But this belongs to theatrical dancing, only suited to those endowed with a particular aptitude for dancing and who make it their profession [...] and for ladies, they should not hop so high. ${ }^{32}$

We know from surviving choreographies, mentioned earlier, that battements, jetés, cabrioles, tours en l'air and even entrechats six were already used extensively by male professional dancers. Their costumes allowed considerable freedom for the legs, and generally sleeves were becoming less restrictive which enabled preparation and balance in jetés and pirouettes. Existing dance notations confirm Rameau's comment that female dancers usually performed far less virtuosic steps than men. 
By 1725, however, women's footwork had become more complex, incorporating turns and jumps. the illustration by Anthony l'Abbé (fl 1688-1738), of a Turkish Dance shows English dancer Elizabeth Younger (fl.1711-34) dancing cabrioles. ${ }^{33}$ Whilst in France Marie-Anne Cupis de Camargo $(1710-1770)$, is reputed to have been able to execute the entrechats quatres (where the feet are crossed and uncrossed, changing four times during one spring into the air), for which she was renowned. ${ }^{34}$ La Camargo, as she was known, made her debut in Paris in 1726, having trained with François Prévost (1680-1741) who, in turn, had succeeded Subligny as principal dancer at the Opéra. Complex footwork was obviously difficult in long skirts - the engraving of Fille de Barquerole dansant la furlana al'Opera shows one solution in the forlana (also known as furlana) - a gigue requiring numerous cuts (where one foot springs into the place of the other, which is simultaneously raised) and successive backward chassés. Here, the dancer is shown wearing flatter, softer shoes on stage, allowing her greater flexibility of the toes and instep. This is a significant practical difference from fashionable shoes which were still stiff and heavy with higher heels, restricting the foot's agility. The dancer is also shown lifting up her skirts to ensure that she did not tread on them while executing rapid chassés backwards. La Camargo excelled in such virtuosic footwork previously only performed by male dancers, and is renowned for shortening her skirts so that her spectacular footwork could be seen. She also began to wear close-fitting knickers known as caleçonde précaution, to preserve her dignity, a necessary addition because at this time women generally never wore such items of underwear. ${ }^{35}$

These are significant examples of how costumes and footwear were beginning to change to accommodate the dancer. Conversely, the 1730 painting of Camargo by Nicholas Lancret (1690-1743) illustrates that a change in the fashionable silhouette for women was being reflected on the stage. Hooped petticoats, known in France as paniers, gave width to 
the skirt, initially in a bell shape, then flattened front and back through the use of tapes underneath to control the shape. The flattening of the hoops allowed partners in a minuet to bow or curtsey face to face, despite the fact that the tapes increased the width. Hoops gave women greater presence simply through the physical space that they inhabited; for the dancer they lifted the fabric of the skirt away from the ankles and allowed much greater freedom of movement for the feet. During the 1730s stage costumes were still fairly inhibiting and the traditional wearing of masks limited the dancers' ability to represent the emotions of the characters they played. Masks made facial expression impossible and were really only used effectively by comic and grotesque dancers whose costumes allowed them the flexibility of movement to affect and influence the spectators' perception of the mask's expression.

While Camargo excelled at feats of technical ability, another outstanding female dancer of this period, Marie Sallé (1707-1756) who is acknowledged to be one of the first female choreographers, sought to develop the expressive and choreographic possibilities of dance. ${ }^{36}$ As the conventions governing dance remained restrictive in France, dancers looked to other courts in Europe for the freedom to develop their art. Many dancers were attracted to London where the lack of state patronage meant that theatre was an entirely commercial enterprise. Furthermore, London audiences were appreciative and receptive to innovation. Foreigners were exotic and intriguing so John Rich imported a great many French dancers, often whole troupes, including notable soloists such as Sallé. Her acting abilities found a natural place in the pantomime tradition in England and she was inspired by the relatively liberal climate she found there. Sallé was notably the first female dancer acknowledged to have both choreographed a production - Pygmalion (1734) - and to have danced in it. She is also famously credited as being the first female who 'dared to appear [...] without a panier, without a skirt [...] no ornament on her head: dressed neither in a corset nor a petticoat, but in a simple muslin robe $[\ldots]$ in the manner of a Greek statue'. ${ }^{37}$ 
There were earlier contenders; Hester Santlow, for example, was described long before in 1723 when appearing as Diana in John Thurmond's 'Masque of Deities', with: [. . . ] her hair loose, a Bow in her hand, and a quiver of Arrows hanging at her Shoulders; a Deer skin fastened to her Breast, a Gown of Purple, tuck'd up to her knees with jewels; her legs adorned with Buskins up to the calf, her Dress, tho' careless, handsome; her behaviour free and easy, tho' modest and decent. ${ }^{38}$

The portrait of the dancer Françoise Prévost, (c.1680-1741) by Jean Raoux (1677-1734) in her role as a Bacchante, also painted in 1723 and now in the collection of the Musée des Beaux-Arts de Tours, gives some impression of this style, although it may only be allegorical and not based upon an actual appearance. It may therefore be more accurate to claim that Sallé was the first 'danseuse seria' trained at the Paris Opéra to be recorded appearing thus.

Actresses had also been appearing in so-called 'breeches roles' (i.e. dressing as men), for decades. Any costuming that exposed the female form was popular with audiences especially the male segment, as they were given an opportunity to view more of the contours of her body than usual. Criticism from commentators, when it came, tended not to be aimed at the performance, but at the performer if her body was considered to be unsuitable to be viewed in this way. ${ }^{39}$ Conversely, when men dressed as women this was seen as burlesque, and was considered amusing, with commentary focusing upon the comedy rather than the body.

In London the introduction of the Theatrical Licensing Act in 1737, and the monopoly given to the patent theatres of Covent Garden and Drury Lane for the performance of serious spoken drama, caused problems in the English theatre which particularly affected dancers. Music and dance had always been an integral part of the presentation of plays but the Licensing Act forced unlicensed theatres, in order to survive, to make these elements a much 
greater part of the evening's entertainment. By dividing the musical presentation into two parts, a play could be performed "gratis" (ie: without charge) in the interval; the legal rules circumvented with pantomimes useful as afterpieces. Such independent theatres also capitalized on the public taste for tumblers, rope dances, burlesque acts and the Italian commedia dell'arte troupes previously enjoyed at the London Fairs. These entertainments began to fill the vacuum left by the Licensing Act's ban on serious drama. Grotesque dancers used their exaggerated movements to great comic effect, and slapstick or harlequinades began to fill the unlicensed English theatres. Such dances are depicted in Gregorio Lambranzi's (fl. 1716) Nuova e curiosa scuola de' ballitheatrali (Figure 7) published in Germany in $1716 .^{40}$ This tradition of antimasque or grotesque dancing was well-established in England and was very popular. Its comic and acrobatic style satisfied public expectations of skill and virtuosity on stage. This change of emphasis in theatre programming had a significant effect on the development of dance. When Drury Lane presented serious drama, dancers who wished to continue working there were forced to accept acting roles. Whilst many actresses had modest dancing proficiency, for professional dancers acting ability now became a desirable skill. This was a radical step, one which led to a phenomenon which would now be referred to as the dancer-actress, in the tradition of Hester Santlow. ${ }^{41}$

'One great leap' for dancers, with the rise of pantomime and a new genre soon to become known as ballet d'action, was the emerging role of the demi-caractère dancer. This term denotes a fusion of the danse noble technique with the more athletic steps and movements of the commedia and grotesque styles. Demi-caractère roles were often danced by young performers on their way up through the ranks. These roles required the same range of technique and style expected from the seria dancer but they allowed for a more diverse range of steps and movements as a contrast or support to the main serious roles. Martello's 
description of Italian dancing describes techniques becoming fashionable in demi-caractère dancing:

(He) displays his spirited dance with great precision; he jumps in the air and there performs nimble caprioles. He comes down on the boards very lightly, on the points of his feet and barely touching the planks he reascends [...] This [...] type of dancing, which is displayed more in the air, is similar to flying. ${ }^{42}$

In 1748 Jean-Baptiste Martin (1659-1735) became costume designer for the Opéra, bringing with him the spirit of the Rococo. ${ }^{43}$ Although still highly decorated, his costume designs appear much lighter, ribbons and pale colours have replaced heavy embroidery. ${ }^{44}$ Martin's demi-caractère figures demonstrate a joie de vivre, with the men in coats and waistcoats, closer to fashionable dress in their lines. He can be credited with introducing the French peasant to the stage, but not in any form that would be recognizable as someone who ever kept animals or milked a cow. Other more exotic characters, Chinese roles for example, could only be recognized from perhaps one item - such as a hat - or from their gestures and stance, since the main part of their costume followed the overall signature style of the period. As before, no attempt was made at accuracy, the desire was to evoke the exotic through adding small touches to a set style of costume. All the women wore wide hoops, and for the male dance noble characters, their tonnelets had swelled to enormous proportions. As Scaramouche was now not the only role where legs and arms were being lifted higher, the old-style costume designs of the Paris Opera had to respond. 
Stage costumes at the Opéra trailed behind the innovations in dance in terms of practicality and suitability for the more natural dance style being employed, especially by the demicaractère dancer. Performances at the Opéra still had to conform to the pattern set by the Royal court as it was the king who sponsored the company. However, some choreographers who had worked outside this narrow milieu began to publicly question the fixed style which this created. One such was Jean-Georges Noverre, who was one of the greatest innovators of ballet style in the century ${ }^{45}$. In 1760 , he lamented:

Greek, Roman, Shepherd, Hunter, Warrior... Laughs, Tritons, Winds, Fires, High Priests ... all these characters are cut to the same pattern and differ only in colour and the ornaments which a desire for ostentatious display rather than good taste causes them to be bespattered. ${ }^{46}$

Noverre was first invited to bring a company to London in the early 1750 s, by the new manager of Drury Lane, the celebrated actor David Garrick (1717-1779). Garrick's more naturalistic acting was replacing the antiquated declamatory style and was similar to Noverre's views on more expressive dancing. Despite the anti-French riots which destroyed his production of Les fêtes Chinoises in 1755, Noverre's time in England, working in Garrick's library, confirmed his determination to develop the new genre ballet d'action in which a story could be told clearly and comprehensively through dance and music alone just as Weaver had tried to do earlier in the century. Noverre returned to London on several further occasions, both to Drury Lane and to the King's Theatre Haymarket, known as the Italian Opera House, where opera and ballet were performed. In 1760 he published his manifesto in the form of Lettres sur la Danse, et sur les Ballets, addressed to an imaginary correspondent, allegedly Jean Dauberval (1742-1806), which was a clarion call for reform. As a choreographer Noverre was keen on depicting realistic narrative and emotional range. He complained that dancers in Paris found themselves trapped in the stiff conventional 
costume designs of previous decades with elaborate headdresses, rigid tonnelets and excessive decoration. Such conventions were still rigidly adhered to, although somewhat modified for the freer arm movements required for gesture.

By the middle of the century the chief costume designer at the Opéra was Louis-René Boquet (1717-1814), who also designed entertainments for the traditional environment of the royal court. His style dominated French costume design for most of the second half of the century. ${ }^{47}$ Many of his drawings survive in the Bibliothèque de l'Opéra in Paris; they have a light, fresh style, with a real sense of movement. However, the feeling of movement his drawings imply seems at odds with the greatly exaggerated hoops and tonnelets worn by the principal dancers, with their decorations of embroidery, swags of flowers and fabric that echoed the fashions of the court. There was still little attempt to suit the style of the costume to the character being played, and foreign dress was barely hinted at, if acknowledged at all.

Noverre reacted strongly against this outmoded style of costume, praising performers who 'discarded tonnelets or those stiff paniers which deprive them of all freedom' and made them 'resemble, as it were, an ill-contrived machine'. ${ }^{48}$ Noverre's ideas were almost certainly influenced by the general growing fascination with the scientific advances which contributed to this part of the eighteenth century being termed 'The Age of Enlightenment'. Noverre strongly endorsed Weaver's lectures on the Anatomical Workings of the Human Body in his own Lettres; which he may have encountered through his teacher, Louis Dupré (1690-1774), who had played the role of Mars in Weaver's seminal work The Loves of Mars and Venus. ${ }^{49}$ Noverre wrote that, 'in my youth I studied osteology which I have found of great advantage in my teaching. This art has taught me [...] the bony structure of man and the levers and hinges which govern its play'. ${ }^{50}$ Studying anatomy had revealed to man that, although he was formed in the image of God, the human body was, in fact, the kind of complex machine to which Noverre alludes. Dupré was responsible for the young Noverre's first professional 
engagement at the Opera Comique in Paris, and is thus a significant link between Weaver's ideas, possibly even his writings, and Noverre who later affirms in his Lettres the importance to a dancer of a knowledge of the mechanical workings of the body. That two significant dancing masters, one in England and one in France, proclaim the essential link between anatomy and movement for the first time in print, demonstrates its place in the development of dance technique.

Noverre believed that the only way to try and develop his ideas of more natural movement and 'Ballet pantomime' was to move away from Paris; first within France at Lyons, and then in Stuttgart (where he was joined by Boquet). Here, the extravagant patronage of Duke Carl Eugen (1728-1793) of Württemberg allowed him to create productions on a grand scale, using the best composers of the time, notably Christoph Willibald Gluck (1714-1787) and Wolfgang Amadeus Mozart (1756- 1791). By this time many of the courts across Europe had set up ballet companies in imitation of the French court, to where prints of Boquet's designs were widely circulated. In Sweden King Gustav III, a patron of the arts founded the Royal Swedish Opera and the Royal Swedish Ballet under the umbrella of the Royal Theatre. Some of the few surviving ballet costumes from the eighteenth century are to be found in the Drottningholm theatre museum in Stockholm. ${ }^{51}$ It is fascinating to observe that the richness of the colours, fabrics and embroidery, combined with the elaborate gold and silver decoration that would have shimmered and glistened in the candlelight, were really as spectacular as the designs would suggest.

By the mid-1760s a more athletic, aerial dance style had developed from the livelier, more acrobatic, Italian manner of dancing, as described earlier. This style evolved from the athletic leaps and exaggerated postures represented in the caricatured personas of the commedia dell' arte tradition, and as a result of the more natural dramatic expression required by ballet d'action. Such change meant that the existing style of costume design was 
no longer appropriate. Noverre, as we have seen, favoured abandoning stiff tonnelets which he claimed would 'transport[... ] the hip to the shoulder and conceal all the contours of the body' and he highlighted the crucial connection between fashion and function when it comes to dance and acting, 'If the style of a ridiculous costume annoys the dancer so that he feels overcome by the weight of his clothes to the extent of forgetting his part, how can he act with ease and warmth? ${ }^{52}$ Following Noverre's advice, his pupil Dauberval championed ballet d'action, helping it evolve with more natural costumes, gestures and facial expression, thereby allowing a greater range of movement and storytelling to be exhibited. It was perhaps Noverre's influence that led the young Maximillian Gardel, dancing as an understudy, to finally abandon both mask and wig in his triumphant debut as Apollo in the 1772 revival of Rameau's Castor et Pollux. ${ }^{53}$

It is difficult to imagine what these performances looked like because very few images survive. Dauberval was depicted with Mlle Allard (1738-1802) in a pas de deux pantomime from the opera Sylvie in the painting of 1766 by Louis Carrogis Carmontelle (1717-1806) which became a popular print by Jean-Baptiste Tilliard (Figure 8). The dancers are shown in a woodland setting, where Allard as the nymph, who only a moment before had been scorning the advances of her admirer Dauberval, has now become aware of the torment she has caused and is turning slightly towards him. Dauberval, meanwhile, is looking away, hopeless, despairing of ever touching her heart. It is a moment of deep emotion. Their costumes show the changes which have been taking place; his tonnelet has become a swathe of fabric around his hips, merely suggesting a similar shape. His shoes are flat and supple, possibly made of leather, while the heels on her shoes are considerably reduced, as are the hoops beneath her skirt. 
It is interesting to compare the image from Sylvie, where the performers have been placed in a more naturalistic setting, with the engraving by Francesco Bartolozzi (1727-1815) of Jason et Medée ballet tragique, published in London in 1781 by John Boydell (Figure 9) which satirizes the ludicrous unsuitability of some costumes still being worn by many dance companies. Bartolozzi's image shows musicians in the pit and the dancers on stage frozen in a moment of high emotional drama. The style of gesture would seem to be similar to that depicted in Sylvie, but their costumes, hoops for the two women and a wide tonnelet for the male lead, strike an incongruous note for such a dramatic and affecting story and for such extreme gestures. Jason et Medée, one of Noverre's most important creations, was first performed in Stuttgart in 1763; the version depicted in Bartolozzi's engraving was the London production - the creation of Gaetan Vestris (1729-1808). ${ }^{54}$ Vestris is shown dancing the leading role of Jason, gazing up and posed in the stock Weaver attitude of astonishment while, to the left, Giovanna Baccelli, (c.1753-1801) as the nymph Creuse, recoils in terror from Medée, danced by Adelaide Simonet $(c .1776-c .1791)$, who clutches a dagger. ${ }^{55}$ This tale of passion and murder was quite shocking to the audiences of the time and marked a new departure in storytelling through dance. ${ }^{56}$

1775 - 1800: REVOLUTION AND ROMANTICISM

In 1776 Noverre achieved his ambition to be appointed ballet master at the Opéra, the highest and most prestigious position available to a choreographer. However, the appointment been made at the command of his former pupil Marie Antoinette, now queen of France, and without attention to precedent. This caused much discontent and his tenure was not a happy one; he resigned in 1781. This underlying resentment towards Noverre had caused him many problems, not least from some of the star performers such as Mlle Guimard $(1743-1818)$. 
She had risen from humble beginnings to become a talented and popular principal dancer. She counted aristocrats among her lovers, whose allowances allowed her to live in some splendour. Guimard was strong minded and very aware of her public and what she felt they expected from her, especially when it came to her costumes. She had no interest in wearing character costumes required by Noverre, believing that she looked best in pale colours, and her desire to control the designs produced for her by Boquet brought her into direct conflict with him. ${ }^{57}$ In 1770, dancing the part of Creuse in Noverre's ballet 'Jason et Medee' in a pale dress, she had used muslin petticoats instead of hoops to give volume to the skirt, and it has been suggested that this may have inspired the style of tutu for 'La Sylphide, ${ }^{58}$ In the finale of the same ballet she appeared as a shepherdess in a costume completely out of keeping with the other dancers. Her chosen style of dress, with the outer skirt pinned up to reveal a petticoat of a different colour, was considered audacious. It had been seen before at the Comédie-Italienne, but never at the Opéra and in the next few days, in a city always ready for the next craze, everyone in Paris had taken up the style and was wearing their own 'Robe à la Guimard'.

By the 1780 s fashionable dress was reflecting the move to neoclassicism, with a slimmer line to female dresses and a rising waistline. The change can also be seen in costume for the ballet, as female dancers begin to appear, sixty years after the infamous experiments by Santlow, Prévost and Sallé, without paniers, in dresses made from flimsier fabrics that revealed more of their bodies and allowed much greater freedom of movement. Such changes led, in turn, to the wearing of flesh-coloured tights, a combination of knickers and long stockings - moves to preserve the dancer's modesty. ${ }^{59}$ This innovation is often attributed to Maillot (d. 1838), a costume designer at the Opéra in the early-nineteenth century, but Guimard, and the French dancer Charles Didelot (1767 - 1837) are both known to have worn them long before in the 1780s and 1790s. Dancers adopted flat pumps, a style which though 
fashionable, evoked the type of footwear which had been worn since the beginning of the century by circus performers and acrobats, the soft leather giving suppleness and grip. ${ }^{60}$ They were far more practical.

In 1789 in Bordeaux, just two weeks before the storming of the Bastille and the outbreak of the French Revolution, Dauberval produced his radical ballet La Fille mal gardée in which, for the first time, ordinary mortals, not deities or heroes, were the main protagonists. ${ }^{61}$ In a bucolic setting, the story revolved around five credible country characters, which in itself was a significant departure, with a plot free of any artificial theatrical effects. It employed action which needed no explanation beyond that of the gestures used by the dancers. This comic ballet revolved around a mother's attempt to marry her only daughter to the witless son of a rich landowner. The daughter, who is already in love with another young man, has other ideas. Dauberval intended that the part of the mother, la Veuve Ragotte (Simone in modern versions), should be played by a man and in the first production it was danced by the popular comedic dancer, M Brochard (dates unknown).

Another print by Bartolozzi (Figure 10) provides some evidence of how the costumes used in this production might have looked. Gaetan Vestris's son Auguste (1760-1842), who had made his debut when he was twelve, had begun to perform in a new style of costume more evocative of the ordinary citizen comprising a simple jacket, shirt and breeches, a style which permitted greater virtuosity and a higher leg line. The young Vestris was noted for spinning endlessly in effortless pirouettes and for high leaps, one spectator remarking that 'he rose towards the sky in such a prodigious manner that he was believed to have wings. ${ }^{62}$ Like many dancers in this period he performed in London as well as Paris on several occasions and his celebrity resulted in a range of images. The London prints show how dance was changing. The noble style, of the elder Vestris, with its bulky tonnelets had slipped gradually out of fashion, although the new, more athletic dance style exhibited by the younger Vestris 
was not universally admired, with critics alluding to performing monkeys, and remarking that 'a goose [could] stand on one leg too'. ${ }^{63}$ The criticism may have been in part because many women in the audience enjoyed the vigorous display of his physical charms. This liberation in dance style is recorded in Gennaro Magri's (fl 1779) treatise, A Practical \& Theoretical Treatise upon Dancing (1779) in which he redefined the positions and steps used in dance, which now included aerial and forced or exaggerated positions for both the legs and the arms, made possible by lighter, less inhibiting costumes. ${ }^{64}$

On the London stage, Rose Parisot (c.1775-c.1837), frequently wore costumes that accentuated her legs as she danced and led the Monthly Mirror to remark that, in a 1796 performance of the ballet le Triomphe de l'Amour, she created 'a stir by raising her legs far higher than was customary for dancers'. ${ }^{65}$ The Bishop of Durham, who had never seen her perform, complained in the House of Lords about, 'female dancers, who, by the allurement of the most indecent attitudes and most wanton theatrical exhibitions succeeded but too effectually in loosening and corrupting the moral feelings of the people. ${ }^{66}$ In response to the outcry, the colour of dancers' tights was changed from light pink or flesh-toned to a more obvious and less provocative white. It was also decreed that the performances were not to extend past midnight; this caused a riot in 1805 when the curtain was brought down before Rose Parisot had finished her solo.

Aerial display became a feature of the male repertoire. Dauberval's pupil, Charles Didelot (1767-1837), began to include simple lifts designed to show man's strength contrasted against a woman's lightness and fragility. Antoine Cardon's engraving of the ballet Achille et Diedamie, shows Andre Jean-Jacques Deshayes (1777-1846) as Achilles disguised as a handmaiden of the Princess Deidamia, being lifted by James Harvey D'Egville (1770-1836) as Ulysses (Figure 11). In his production of 'Flore et Zephyr' in 1776, Didelot took another great leap. With the aid of almost invisible wires, his dancers in light, simple 
costumes could be lifted or lowered, appearing to fly across the stage or stand en pointe. Such elevation was truly astonishing and the stage was set for the development of what we now term Romantic ballet.

\section{CONCLUSION}

The French court had dominated taste and culture in Europe for the hundred years leading up to the revolution of 1789 . The fact that ballet terms, even today, are still in French is a direct result of Louis XIV's founding of the Académie Royale de Dance in 1661, and many of the great ballet companies of Europe were founded during this period in imitation of the French tradition, including the Danish Royal Ballet was in 1748, the Swedish Royal Ballet in 1773 and the Bolshoi in 1776. In England ballet culture was independent and commercially driven throughout the eighteenth century; Great Britain did not have a royal Ballet company until 1956. However, in codifying the dance, the Académie, by its very nature, set ballet on a restrictive path. It was the influence and innovation practiced in other cities: Lyons and Bordeaux within France, and Vienna, Stuttgart, and especially London, that allowed ballet to flourish and develop into the vibrant art form seen today. At the dawn of the century, machines had been used to help magnificently robed deities descend from the heavens to the earth below; as the century closed, man himself had the opportunity, unencumbered by heavy costumes, with an athletic body and spirits suitably inspired, to leave the earth and ascend to heaven - a great leap indeed.

\section{REFERENCES}

\footnotetext{
${ }^{1}$ OED Online (Oxford University Press, December 2014. Web. 14 February 2015) defines ballet as, 'A dramatic entertainment consisting of dance and mime performed to music; (in early use) a theatrical spectacle intended to illustrate the costumes and culture of other nations, or to dramatise through music and dance some myth or narrative; (later) a theatrical dance performance using precise and highly formalised set steps and techniques'. <http://www.oed.com/view/Entry/14949?rskey=5eN3Z0\&result=1\#eid> [accessed 14 February 2015].
} 
${ }^{2}$ See Susan Au, Ballet and Modern Dance (London: Thames \& Hudson 2002) p. 24-26. The ballet school of the Paris Opera, still in existence today, was founded in 1713 to train professional dancers for the stage.

${ }^{3}$ Pierre Rameau, Le Maître à danser (Paris, 1725) trans. by Cyril W. Beaumont (New York: Dance Horizons 1970), pp. ix-x. For biographical detail see: Graham Sadler, The Rameau Compendium (Woodbridge: Boydell Press 2014).

${ }^{4}$ Danse noble and other terms associated with dancing techniques in late-seventeenth century France are discussed in Jennifer Thorp, 'Pecour's Allemande, 1702-1765: How German was it?' in Eighteenth-Century Music, 1:2 (2004), p. 183-204.

5 James Laver, Drama: Its Costume and Décor (London: The Studio Publications, 1951) p. 150.

${ }^{6}$ Details of Subligny's career are found in Philip H. Highfill, Kalman A. Burnim, Edward A. Langhans, $A$ Biographical Dictionary of Actors, Actresses, Musicians, Dancers, Managers, and Other Stage Personnel in London, 1660-1800 (Carbondale: Southern Illinois University 1991) Vol 14 p.328-329

${ }^{7}$ Tonnelet is the French word for a little barrel, which aptly describes the shape that the male tunic skirt began to take, as designers added small hoops of a similar shape to those worn by women, to denote leading characters. The term half-aerial was defined by Gennaro Magri, whose 1779 treatise, Trattato Teoricicoprattico di Ballo, is one of the leading publications about eighteenth-century dance technique, see Deborah Crane \& Judith Mackrell Oxford Dictionary of Dance (Oxford: Oxford University Press, 2010), p.290.

${ }^{8}$ Details of Ménestrier's career can be found in Marian Hannah Winter, The Pre-Romantic Ballet (London: Pitman Publishing, 1974) pp.7-12

${ }^{9}$ Père Ménestrier, Des Ballets Anciens et Modernes (Paris: Rene Guignard, 1682), p. 255.

${ }^{10}$ Details of Balon's career can be found in Highfill, Burnim and Langhans, Biographical Dictionary, Vol. I, pp. 239-40.

${ }^{11}$ For Jean Baptiste Lully see Alison Latham (edit) The Oxford Companion to Music (Oxford: Oxford University Press 2002)

${ }^{12}$ See Au Ballet and Modern Dance p. 26-27.

${ }^{13}$ A coryphée is a rank above the chorus but below soloist; usually dances in a small group. See: Sandra Noll Hammond, 'The Rise of Ballet Technique and Training: The Professionalization of an Art Form' in Cambridge Companion to Ballet, ed. Marion Kant (Cambridge: Cambridge University Press, 2007) p. 65-77

${ }^{14}$ Rigaudon de Vaisseaux, Recueil de dances, composées par M. Pecour [...] et mise sur le papier par M. Feuillet, ( Paris : L'auteur et M. Brunet 1700). See : Ferdianado Reyna A Concise History of Ballet (London: Thames \& Hudson 1965) pp. 54-56.

${ }^{15}$ Kellom Tomlinson, The Art of Dancing (New York: Dance Horizons 1970), p. 151. Details of Kellom Tomlinson's career can be found in Highfill, Burnim and Langhans, Biographical Dictionary, Vol. 15 pp. 21-23.

${ }^{16}$ Laver, Drama, p. 150.

${ }^{17}$ Rameau, Le Maître à danser, p.xii.

${ }^{18}$ See Richard Ralph, The Life and Works of John Weaver (London: Dance Books, 1985), p. 743. 
19 Pier Jacopo Martello, Della tragedia antica e moderna (Rome 1715) discussed in Winter, The Pre-Romantic Ballet, p.65.

${ }^{20}$ See, Lincoln Kirstein, Fifty Ballet Masterworks (New York: Dover Publications, 1984) p. 70, Laver, Drama - Its Costume and Décor, p. 112, and Roy Strong, Ivor Guest, Richard Buckle, Barry Kay, Liz da Costa, Designing for the Dancer (London: Elron Press 1981), p. 14.

${ }^{21}$ Laver, Drama, p. 152, and Martin Eidelberg, 'Watteau and Gillot: A Point of Contact', The Burlington Magazine, (1973 Vol. 115, No. 841, pp. 232-239

22 Strong et al, Designing for the Dancer, p. 36.

${ }^{23}$ Costume designs by Claude Gillot, Jean-Baptiste Martin and Louis-Rene Boquet can be viewed in the Bibliotheque National de France digital catalogue <http://gallica.bnf.fr/>

${ }^{24}$ Ralph, The Life and Works of John Weaver, p. 743.

${ }^{25}$ For Hester Santlow see: Moira Goff The Incomparable Hester Santlow: A Dancer-actress on the Georgian Stage, (London: Ashgate 2007).

${ }^{26}$ Sybil Rosenfeld, The Theatre of the London Fairs in the Eighteenth Century (Cambridge: Cambridge University Press, 1960), p. 146

27 Elizabeth Miller Lewis ‘Hester Santlow's Harlequine: Dance, Dress, Status and Gender on the London Stage, 1704-1734, in The Clothes That Wear Us ed. by Jessica Munns and Penny Richards (Newark: University of Delaware Press, 1999) p 80-101.

${ }^{28}$ Pierre Rameau, The Art of the Dancing Master Explained trans. John Essex (London: J. Brotherton 1728).

29 Benjamin Victor, Memoirs of the Life of Barton Booth, Esq. (London: J. Watts 1733), pp. 49-51.

${ }^{30}$ Winter, The Pre-Romantic Ballet, gives a date for the engraving as 'pre 1711 '.

31 Pierre Rameau, The Dancing Master trans. by Cyril Beaumont (Dance Horizons 1970), p.12.

32 Rameau, The Dancing Master, pp. 94-95 \& 110

33 For Anthony L'Abbe, see 'A New Collection of Dances', in Music for London Entertainment 1660-1800 Series $D$ (London: Stainer and Bell, 1991); and for Elizabeth Younger see Highfill et al., Biographical Dictionary, Vol. 16, pp. 362-64.

${ }^{34}$ See Au Ballet and Modern Dance p. 31

35 James Laver, Costume in the Theatre (London: George Harrap, 1964) p.165, and Strong, Guest, Buckle, Designing for the Dancer, p. 36. Arlene Cooper, La Camargo's Skirt: The Eighteenth Century Ballet Re-dressed in Dress Vol. 10 (Philadelphia: Maney Publishing 1984) pp. 33-42

${ }^{36}$ See Au Ballet and Modern Dance pp. 31-32

${ }^{37}$ Mercure de France, April 1764, pp. 770 - 772. 
38 John Thurmond, Three Entertainments Performed at Theatre Royal Drury Lane (London, 1727), pp. 17 - 18.

39 Shearer West, 'Beauty, Aging and the Body Politic' in The First Actresses, ed. by Gill Perry (London: National Portrait Gallery 2011) p. 110.

${ }^{40}$ Gregorio Lambranzi New and Curious School of Theatrical Dancing: The Classic Illustrated Treatise on Commedia dell'Arte Performance (New York: Dover Publications 2003)

${ }^{41}$ Moira Goff, 'In Pursuit of the Dancer Actress', Women's Work: Making Dance in Europe before 1800, ed. by Lynn Brooks (Madison: University of Wisconsin Press 2008 p. 183)

42 Martello, Della Tragedia, p. 313.

43 The symmetrical grandiose style of the Baroque, gave way to the Rococo (from the French word Rocaille rocks), a style based on natural forms, especially shells, from which were derived abstract ornaments in $\mathrm{S}$ and $C$ shapes, with asymmetrical twists. It was a lighter, more capricious style that spread to all forms of decoration.

44 Examples of these costumes can be viewed online at the Museum of Fine Arts, Boston, Massachusetts. An example of Martin's costume design can be seen at http://collections.vam.ac.uk/item/0577793/reine-desylphesfashion-plate-martin-jean-baptiste

${ }^{45}$ See Michael Burden and Jennifer Thorp The Works of Monsieur Noverre Translated from the French: Noverre, his circle, and the English Lettres sur la Danse (New York: Pendragon Press 2014) and Deryck Lynham The Chevalier Noverre (London: Dance Books 1972)

46 Jean-Georges Noverre, Letters on Dancing and Ballets, trans. By Cyril Beaumont (New York: Dance Horizons 1975), p. 73.

47 Laver, Drama - Its Costume and Décor, pp. 154-155.

${ }^{48}$ Noverre, Letters on Dancing and Ballets, p. 75.

${ }^{49}$ Ralph, The Life and Works of John Weaver, p. 855-1031.

${ }^{50}$ Lynham, Chevalier Noverre, p. 138.

${ }^{51}$ See Lena Rangstrom, Modelejon Manligt Mode (Helsingfors : Atlantis, 2003)

${ }^{52}$ Noverre, Letters on Dancing and Ballets, p. 74.

${ }^{53}$ Ivor Guest Ballet of the Enlightenment (London: Dance Books 1996) p.51

54 Gaetano Apolline Baldassarre Vestris (1729 - 1808) - French ballet dancer who studied with Louis Dupré at the Academie Royale in Paris and later the Opéra where he became dancing master to Louis XVI. Highfill et al., Biographical Dictionary, Vol. 15, pp. 146-50.

55 Giovanna Bacelli (d 1801) made her debut at the Kings Theatre in Nov 1774 and danced in operas, divertissements and pantomimes. See: Karen Eliot, Dancing Lives: Five Female Dancers from the Ballet D'Action to Merce Cunningham (Chicago: University of Illinois Press 2007) pp. 7-32. Highfill et al., Biographical Dictionary, Vol. 14, pp. 78-79. 
${ }^{56}$ Moira Goff, John Goldfinch, Karen Limper-Hertz, and Helen Peden (eds), Georgians Revealed: Life, Style \& the Making of Modern Britain ed. (London: British Library 2013) p. 107.

${ }^{57}$ Guest Ballet of the Enlightenment. pp. 35-39

58 Judith Chazin-Bennahum, The Lure of Perfection: Fashion and Ballet, 1780 - 1830 (New York: Routledge, 2005) p.47.

${ }^{59}$ Chazin-Bennahum, The Lure of Perfection, pp. 105-7.

${ }^{60}$ Chazin-Bennahum, The Lure of Perfection, pp. 103

61 The work premiered as a musical pastiche known as Le Ballet de la Paille (Ballet of the Straw) and was later renamed. It was first performed in London in 1791. See Guest Ballet of the Enlightenment, pp. 386-388 \& 396.

${ }^{62}$ Victoria \& Albert Museum, The origins of ballet. http://www.vam.ac.uk/content/articles/o/origins-of-ballet/ accessed 29/05/2015

${ }^{63}$ Victoria \& Albert Museum, The origins of ballet.

64 Genaro Magri, TrattatoTeoricico-prattico di Ballo 1779. Magri's birth and death dates are unrecorded so his career is difficult to trace. For known details see Mary Skeaping with Armgard Berry, Theoretical and practical treatise on dancing:Gennaro Magri, Naples 1779 (London: Dance Books, 1988), pp. 9-10

${ }^{65}$ Victoria \& Albert Museum, The origins of ballet.

${ }^{66}$ Andrew McConnell, The Pantomime Life of Joseph Grimaldi: Laughter, Madness and the Story of Britain's Greatest Comedian. (Edinburgh: Canongate Books, 2009), p. 144.

\section{Mary Collins}

Mary Collins is an Early Dance specialist, reviving original choreography and gesture for historical performance. She works with dance, theatre and television companies as an adviser, choreographer, dancer and actress and tours regularly giving master-classes, lecture-recitals and workshops. Mary teaches at the Royal Academy of Music and Royal College of Music in London and is also a faculty member of Aestas Musica in Croatia and the Austria Barock Akademie. She regularly works with many of the world's leading exponents of early music. 


\section{Joanna Jarvis}

Joanna Jarvis trained in Theatre Design and currently lectures on the Theatre Performance \& Event Design course at Birmingham City University (BCU). She is also a freelance costume designer and maker, specialising in period costume. Her long association with Mary Collins has led to a particular interest in period dance and how the cut of clothes affects movement. She is currently studying for a doctorate at BCU, examining the relationship between costume for dance, fashion and female body image in the late eighteenth-century.

She is currently studying for a doctorate at BCU, examining the relationship between costume for dance, fashion, and female body image in the late eighteenth century. 